\title{
Responses of Nili-Ravi buffalo to aflatoxin B1 with and without toxin adsorbents
}

\author{
R. Akhtar ${ }^{1,4}$, M. Sardar', N. Saima², G. Saleem 1 , S. Imran ${ }^{3}$ and A. Aslam ${ }^{1}$ \\ University of Veterinary and Animal Sciences, \\ ${ }^{1}$ Department of Pathology, Faculty of Veterinary Sciences, ${ }^{2}$ Department of Animal Nutrition, ${ }^{3}$ Department of Surgery \\ Sheikh Abdul Qadir Jilani Road, 54000 Lahore, Pakistan
}

KEY WORDS: buffalo, activated charcoal, aflatoxin B1, glucomannan, HSCAS

Received: 1 September 2014

Revised: 11 December 2014

Accepted: 15 December 2014

${ }^{4}$ Corresponding author:

e-mail: teetu_meetu41@yahoo.com

or raheela.akhtar@uvas.edu.pk

\begin{abstract}
The objective of the study was to determine the responses of Nili-Ravi buffalo to aflatoxin B1 (AFB1) in terms of feed intake, haematologi$\mathrm{cal}$ and serum biochemical parameters and to compare the efficacy of three different toxin adsorbents against AFB1. Twenty-five Nili-Ravi buffaloes were selected from a herd and were divided into five groups for a period of 21 days to receive: no aflatoxin B1 (AFB1) in the diet, a diet contaminated with AFB1, a diet contaminated with AFB1 with the addition of one of three different toxin adsorbents: glucomannan, hydrated sodium calcium aluminosilicate (HSCAS), or activated charcoal at an inclusion level of $0.2 \%$ of feed. AFB1 was incorporated into feed at an inclusion level of $500 \mu \mathrm{gg} \cdot \mathrm{kg}^{-1}$ per animal per day. The results indicate that the average daily feed intake of AFB1-treated buffaloes significantly declined $(P<0.05)$ compared with the control. Serum levels of total bilirubin, alkaline phosphatase (ALP), alanine aminotransferase (ALT), aspartate aminotransferase (AST) and creatinine were significantly increased $(P<0.05)$ in response to AFB1, but the change in blood urea nitrogen (BUN) levels was nonsignificant $(P>0.05)$. In haematology, the total erythrocyte count (TEC), total leukocyte count (TLC), haemoglobin concentration (HGB), haematocrit levels (HCT), mean corpuscular haemoglobin (MCH) and mean corpuscular haemoglobin concentration (MCHC) decreased significantly $(P<0.05)$ in the AFB1 group on days 14 and 21 of the experiment. From among the three toxin adsorbents, $0.2 \%$ glucomannan significantly $(P<0.05)$ improved the feed intake levels of buffaloes and also significantly $(P<0.05)$ minimized the AFB1-induced adverse effects on haematology and serum biochemistry, but was unable to totally ameliorate its effect, while HSCAS was less effective, and activated charcoal, the least.
\end{abstract}

\section{Introduction}

Buffalo, with a population numbering about 33.7 million, is the main milk-producing animal in Pakistan; the major buffalo breed contributing to milk production is Nili-Ravi, known as the black gold of Pakistan (Ahmad, 2013). The livestock sector of
Pakistan is presently facing many challenges, one of which is mycotoxin contamination of feedstuffs (Sultana and Hanif, 2009). The hot and humid climatic conditions in Pakistan favour the growth of fungi like Aspergillus flavus and Aspergillus parasiticus (Royes and Yanong, 2002). According to a study in Pakistan, $97.3 \%$ samples of compound feed were found to be 
contaminated with aflatoxin B1 (AFB1) and almost $51.6 \%$ positive AFB1 samples had a level greater than the maximum permitted by European Commission legislation (Sultana et al., 2013). Among the mycotoxins, AFB1 is of major concern regarding its conversion into aflatoxin M1 (AFM1) in milk (Var et al., 2008). Previous studies have shown that aflatoxin toxicity may result in significant changes in haematological and serum biochemical parameters and that in chronic aflatoxin toxicity, changes in these parameters may occur before the appearance of clinical signs (Donmez and Keskin, 2008). No such study has been conducted, however, on the responses of Nili-Ravi buffaloes, therefore, this is the first study to address this question.

An effective way to overcome the mycotoxin problem is the use of mycotoxin adsorbent materials, such as like hydrated sodium calcium aluminosilicates (HSCAS), bentonites, activated carbon, that adsorb mycotoxins and make them unavailable for absorption in the intestines (Diaz et al., 2003). Taking into account all of these points, our study was conducted with the aim to analyse the effect of AFB1 on feed intake, haematology and serum biochemistry in Nili-Ravi buffaloes. The second objective of the study was to analyse the comparative efficacy of three different toxin adsorbents [(glucomannan, hydrated sodium calcium aluminosilicate (HSCAS)] and activated charcoal) against AFB1.

Nili-Ravi buffalo were chosen for this study because this breed has a major share in milk production in Pakistan and, to our knowledge, this is the first study in this breed.

\section{Material and methods}

\section{Aflatoxin B1 production}

Aspergillus flavus strain NRRL 2999 was used to produce AFB1 on rice medium according to Shotwell et al. (1966). The A. flavus strain was obtained from the Department of Microbiology, UVAS Lahore (Pakistan). After production, AFB1 was purified and quantified by thin-layer chromatography (TLC) at the Department of Pathology, UVAS Lahore (Pakistan).

\section{Thin-layer chromatography (TLC)}

After fermentation of rice according to Shotwell et al. (1966), $30 \mathrm{~g}$ was collected and mixed with chloroform $(60 \mathrm{ml})$. Extraction was performed by refluxing for $4 \mathrm{~h}$, after which the extract was filtered through cheesecloth. For maximal AFB1 recovery, the process was repeated for a total of three extractions. The filtrate was dried over a TLC plate and transferred to a chromatography tank. The plate was developed in a 3:97 (v/v) mixture of methanol and chloroform. AFB1 was quantified by visual comparison of the fluorescence zone with a known quantity of aflatoxin standards. AFB1 was obtained by excising the fluorescence zone along with the stationary phase and storing it at $-20^{\circ} \mathrm{C}$.

\section{AFB1 incorporation in feed}

The chemical composition of the concentrate offered to the animals is shown in Table 1. Pure quantified AFB1 (500 $\left.\mu \mathrm{g} \cdot \mathrm{kg}^{-1}\right)$ was dissolved in methanol and mixed with the concentrate feed to ensure proper intake by the animals.

Table 1. Chemical composition of concentrate offered to animals

\begin{tabular}{ll}
\hline Ingredients & Content, \% \\
\hline Dry matter & 88 \\
Crude protein & 18 \\
Ether extract & 2.9 \\
Ash & 1.6 \\
\hline
\end{tabular}

\section{Estimation of AFB1 concentration in feed}

Direct competitive enzyme-linked immunosorbent assay (ELISA) was used for detecting AFB1 in feed by using Affinitech kits (AffiniTech Ltd., USA). A ground sample of feed (5 g) was added to $25 \mathrm{ml}$ of $70 \%$ methanol and shaken vigorously for $3 \mathrm{~min}$. The extract was filtered by pouring 5-10 $\mathrm{ml}$ through Whatmann \#1 filter paper and the filtrate was collected. Then $100 \mu \mathrm{l}$ of the conjugate was added to $100 \mu \mathrm{l}$ 109 of sample and standards in each mixing well of ELISA plate. The liquid in the wells was mixed by pipetting it up and down three times. Next, $100 \mu \mathrm{l}$ of the liquid was transferred to the antibody-coated wells. The plates were incubated for 2 min with shaking every 10-20 sec. The well contents were shaken out and the wells were washed with distilled water. This step was repeated 5 times. Then $100 \mu \mathrm{l}$ of substrate was added to each well and the plates were again incubated for 3 min. The plates were then emptied and the wells rinsed with distilled water. After this, $100 \mu 1$ of stop solution was added. The bottoms of the micro-wells were wiped with a dry cloth and the reading in an ELISA Reader ELx800 (Bio-Tek) was taken at $650 \mathrm{~nm}$.

\section{Animals and diets}

The trial was conducted at the Livestock Experimental Station, Haroonabad (Pakistan), using 25 Nili-Ravi buffaloes. The animals were kept on the experimental diets for 21 days. The buffaloes were divided into five groups. Each group consisted of five animals. One group (control) received a diet containing no aflatoxin or toxin adsorbent, the AFB1 group 
was offered a diet containing $500 \mu \mathrm{g} \cdot \mathrm{kg}^{-1}$ AFB1 per animal per day with no toxin adsorbent (positive control), the glucomannan (GM) group was offered a diet containing $500 \mu \mathrm{g} \cdot \mathrm{kg}^{-1}$ AFB1 supplemented with $0.2 \% \mathrm{GM}$ ), the hydrated sodium calcium aluminosilicates (HSCAS) group was offered a diet containing $500 \mu \mathrm{g} \cdot \mathrm{kg}^{-1}$ AFB1 supplemented with $0.2 \%$ HSCAS, and the activated charcoal (AC) group was offered a diet containing $500 \mu \mathrm{g} \cdot \mathrm{kg}^{-1}$ AFB1 supplemented with $0.2 \% \mathrm{AC}$. All three adsorbents were added at an inclusion level of $0.2 \%$ of feed dry matter per animal per day.

\section{Experimental parameters studied}

Feed intake. Average daily feed intake was determined by weighing feed offered and feed refused by the animals on a dry matter basis.

Haematology and serum biochemistry. Blood and serum samples were collected from all five groups on days $0,7,14$ and 21 of feeding the toxin-containing feeds. Serum levels of alkaline phosphatase (ALP), aspartate aminotransferase (AST), alanine transaminase (ALT), total bilirubin, blood urea nitrogen (BUN) and creatinine were analysed by a URIT-800 chemistry analyser (URIT, China); haematology comprised a complete blood count (CBC), which included total erythrocyte count (TEC), total leukocyte count (TLC), haemoglobin level (HGB), haematocrit (HCT), mean corpuscular volume (MCV), mean corpuscular haemoglobin $(\mathrm{MCH})$ and mean corpuscular haemoglobin concentration (MCHC) as determined by a haematological analyser (Abacus junior vet, Diatron).

\section{Statistical analysis}

The obtained data was subjected to statistical analysis using the Completely Randomized Design (CRD) option of the Statistix statistical package (Copyright 1985-2005 Analytical Software, USA) with Duncan's Multiple Range Test for comparison of means.

\section{Results}

\section{Feed intake}

The average daily feed intake levels of buffaloes (Figure 1$)$ decreased significantly $(P<0.05)$ when they were fed the diet contaminated with $500 \mu \mathrm{g} \cdot \mathrm{kg}^{-1}$ AFB1. Supplementation of $0.2 \%$ glucomannan to the AFB1-treated diet significantly improved feed intake $(P<0.05)$ compared with the group fed AFB1-contaminated feed alone, but this improvement was still below the control group. The study revealed that among the three toxin adsorbents used, supplementation of contaminated feed with glucomannan at $0.2 \%$ of feed dry matter (DM) significantly improved feed intake levels, but did not completely overcome the effect of AFB1. Supplementation of HSCAS at $0.2 \%$ of DM to contaminated feed nonsignificantly $(P>0.05)$ reduced the AFB1 effect, whereas supplementation of activated charcoal at the same concentration failed to show a significant effect $(P>0.05)$.

\section{Serum biochemistry}

Serum levels of ALT, AST, ALP and total bilirubin in buffaloes fed AFB1-contaminated feed increased

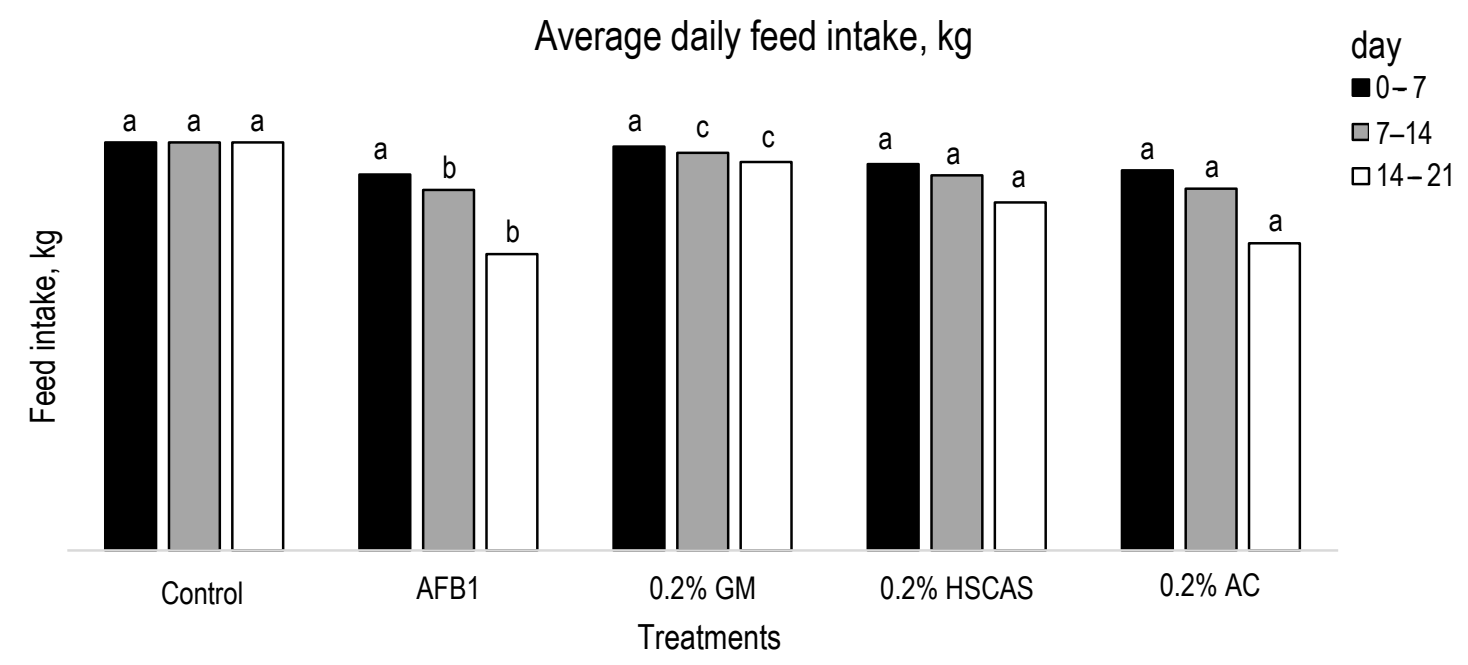

Figure 1. Average daily feed intake $(\mathrm{kg})$ in Nili-Ravi buffalo fed on $500 \mu \mathrm{gg} \cdot \mathrm{kg}^{-1}$ aflatoxin B1 contaminated feed with three different toxin adsorbents. AFB1 - aflatoxin B1 treated group without any toxin adsorbent; $0.2 \% \mathrm{GM}-0.2 \%$ glucomannan treated group; $0.2 \%$ HSCAS - $0.2 \%$ hydrated sodium calcium aluminosilicate treated group; $0.2 \% \mathrm{AC}$ - activated charcoal treated group; ${ }^{a, b, c}$ means with different superscripts differ significantly at $P<0.05$ 
significantly $(P<0.05)$. Serum creatinine levels were significantly increased $(P<0.05)$ on days 14 and 21 of the experiment, and no significant change $(P>0.05)$ was noted in blood urea nitrogen $(\mathrm{BUN})$ levels in AFB1-treated buffaloes. Among the three toxin adsorbents, supplementation of $0.2 \%$ glucomannan to the AFB1-contaminated dietsignificantly reduced $(P<0.05)$ the increase in total bilirubin, ALP, ALT, and AST, but did not return them to normal levels. The results showed that $0.2 \%$ HSCAS supplementation to

Table 2. Means of alkaline phosphatase (ALP), alanine aminotransferase (ALT), aspartate aminotransferase (AST) levels in Nili-Ravi buffalo fed on $500 \mu \mathrm{g} \cdot \mathrm{kg}^{-1}$ AFB1 contaminated feed with three different toxin adsorbents

\begin{tabular}{|c|c|c|c|c|c|c|}
\hline $\begin{array}{l}\text { Enzymes, } \\
\mathrm{U} / \mathrm{I}\end{array}$ & 'Days & Control & AFB ${ }^{1}$ & $\begin{array}{l}0.2 \% \\
\mathrm{GM}^{2}\end{array}$ & $\begin{array}{l}0.2 \% \\
\text { HSCAS }^{3}\end{array}$ & $\begin{array}{l}0.2 \% \\
\mathrm{AC}^{4}\end{array}$ \\
\hline \multirow[t]{4}{*}{ ALP } & 0 & $108.40^{\mathrm{a}}$ & $108.45^{a}$ & $108.49^{a}$ & $108.43^{a}$ & $108.41^{a}$ \\
\hline & 7 & $108.40^{\mathrm{b}}$ & $112.04^{\mathrm{a}}$ & $109.19^{b}$ & $110.94^{a}$ & $112.16^{a}$ \\
\hline & 14 & $108.40^{d}$ & $113.84^{a}$ & $110.21^{c}$ & $112.14^{b}$ & $113.56^{a}$ \\
\hline & 21 & $108.4^{d}$ & $114.82^{\mathrm{a}}$ & $110.47^{c}$ & $113.36^{b}$ & $114.56^{\mathrm{ab}}$ \\
\hline \multirow[t]{4}{*}{ ALT } & 0 & $25.98^{\mathrm{a}}$ & $25.91^{\mathrm{a}}$ & $25.97^{\mathrm{a}}$ & $25.84^{a}$ & $25.94^{\mathrm{a}}$ \\
\hline & 7 & $25.98^{c}$ & $30.07^{a}$ & $26.47^{\mathrm{bc}}$ & $27.74^{b}$ & $29.69^{a}$ \\
\hline & 14 & $25.98^{d}$ & $33.87^{a}$ & $27.37^{\circ}$ & $29.34^{b}$ & $33.29^{a}$ \\
\hline & 21 & $25.98^{d}$ & $34.67^{\mathrm{a}}$ & $28.37^{c}$ & $31.14^{b}$ & $34.29^{a}$ \\
\hline \multirow[t]{4}{*}{ AST } & 0 & $99.73^{a}$ & $99.67^{a}$ & $99.76^{a}$ & $99.69^{a}$ & $99.72^{\mathrm{a}}$ \\
\hline & 7 & $99.73^{c}$ & $104.03^{\mathrm{a}}$ & $100.79^{b c}$ & $102.06^{b}$ & $103.55^{\mathrm{a}}$ \\
\hline & 14 & $99.73^{d}$ & $105.49^{a}$ & $101.59^{c}$ & $103.86^{b}$ & $105.15^{\mathrm{ab}}$ \\
\hline & 21 & $99.73^{d}$ & $106.69^{\mathrm{a}}$ & $101.32^{c}$ & $104.66^{\mathrm{b}}$ & $106.35^{a}$ \\
\hline
\end{tabular}

${ }^{1} \mathrm{AFB} 1$ - aflatoxin B1 treated group without any toxin adsorbent; ${ }^{2} 0.2 \%$ GM $-0.2 \%$ glucomannan treated group; ${ }^{3} 0.2 \%$ HSCAS $-0.2 \%$ hydrated sodium calcium aluminosilicate treated group, ${ }^{4} 0.2 \% \mathrm{AC}-02 \%$ activated charcoal treated group; $\mathrm{a}, \mathrm{b}, \mathrm{c}, \mathrm{d}$ means with different superscripts within a row differ significantly at $P<0.05$

Table 3. Average mean of total bilirubin, creatinine, blood urea nitrogen levels in Nili-Ravi Buffalo fed on $500 \mu \mathrm{g} \cdot \mathrm{kg}^{-1}$ AFB1 contaminated feed with three different toxin adsorbents

\begin{tabular}{lcccccc}
\hline $\begin{array}{l}\text { Parameter, } \\
\mathrm{mg} \cdot \mathrm{dl}^{-1}\end{array}$ & Days & Control & AFB1 & $\begin{array}{l}0.2 \% \\
\mathrm{GM}^{2}\end{array}$ & $\begin{array}{l}0.2 \% \\
\text { HSCAS }\end{array}$ & $\begin{array}{l}0.2 \% \\
\text { AC }^{4}\end{array}$ \\
\hline Total bilirubin & 0 & $0.39^{\mathrm{ab}}$ & $0.38^{\mathrm{b}}$ & $0.39^{\mathrm{ab}}$ & $0.40^{\mathrm{ab}}$ & $0.42^{\mathrm{a}}$ \\
& 7 & $0.39^{\mathrm{ab}}$ & $0.51^{\mathrm{a}}$ & $0.47^{\mathrm{b}}$ & $0.47^{\mathrm{b}}$ & $0.47^{\mathrm{b}}$ \\
& 14 & $0.39^{\mathrm{ab}}$ & $0.88^{\mathrm{a}}$ & $0.62^{\mathrm{c}}$ & $0.75^{\mathrm{b}}$ & $0.85^{\mathrm{a}}$ \\
& 21 & $0.39^{\mathrm{ab}}$ & $1.17^{\mathrm{a}}$ & $0.69^{\mathrm{c}}$ & $0.90^{\mathrm{b}}$ & $1.15^{\mathrm{a}}$ \\
& & & & & & \\
Creatinine & 0 & $1.15^{\mathrm{a}}$ & $1.16^{\mathrm{a}}$ & $1.18^{\mathrm{a}}$ & $1.15^{\mathrm{a}}$ & $1.18^{\mathrm{a}}$ \\
& 7 & $1.15^{\mathrm{a}}$ & $1.22^{\mathrm{ab}}$ & $1.22^{\mathrm{ab}}$ & $1.19^{\mathrm{ab}}$ & $1.23^{\mathrm{a}}$ \\
& 14 & $1.15^{\mathrm{a}}$ & $1.61^{\mathrm{a}}$ & $1.37^{\mathrm{b}}$ & $1.56^{\mathrm{a}}$ & $1.62^{\mathrm{a}}$ \\
& 21 & $1.15^{\mathrm{a}}$ & $1.99^{\mathrm{a}}$ & $1.57^{\mathrm{c}}$ & $1.82^{\mathrm{b}}$ & $1.97^{\mathrm{a}}$ \\
& & & & & & \\
& 0 & $18.63^{\mathrm{a}}$ & $18.73^{\mathrm{a}}$ & $18.79^{\mathrm{a}}$ & $18.71^{\mathrm{a}}$ & $18.74^{\mathrm{a}}$ \\
& 7 & $18.63^{\mathrm{a}}$ & $18.75^{\mathrm{a}}$ & $18.78^{\mathrm{a}}$ & $18.76^{\mathrm{a}}$ & $18.79^{\mathrm{a}}$ \\
& 14 & $18.63^{\mathrm{a}}$ & $18.97^{\mathrm{a}}$ & $18.71^{\mathrm{a}}$ & $18.93^{\mathrm{a}}$ & $19.01^{\mathrm{a}}$ \\
& 21 & $18.63^{\mathrm{a}}$ & $19.40^{\mathrm{a}}$ & $18.98^{\mathrm{a}}$ & $19.31^{\mathrm{a}}$ & $19.43^{\mathrm{a}}$ \\
\hline
\end{tabular}

$1,2,3,4$ see Table 2; BUN - blood urea nitrogen; ${ }^{a, b}$ means in the same rows having different superscripts show significant differences from each other at $P<0.05$ a contaminated diet also significantly $(P<0.05)$ reduced the hepatotoxic effect of AFB1 on day 21 of the experiment compared with buffaloes fed the AFB1contaminated diet without any adsorbent, but its efficacy was lower compared with glucomannan. Our results showed that the levels of ALT, AST, ALP and total bilirubin in the $0.2 \%$ activated charcoal group were nonsignificantly $(P<0.05)$ different from the AFB1-treated group (Tables 2 and 3).

\section{Haematology}

There was a significant decrease $(P<0.05)$ in TEC, TLC, HGB, HCT, MCH and MCHC levels in AFB1-treated buffaloes compared with the control. Among haematological parameters, no significant

Table 4. Average means of haemoglobin, haematocrit, mean corpuscular volume, mean corpuscular haemoglobin and mean corpuscular haemoglobin concentration levels in Nili-Ravi buffalo fed on $500 \mu \mathrm{g} \cdot \mathrm{kg}^{-1}$ AFB1 contaminated feed with three different toxin adsorbents

\begin{tabular}{|c|c|c|c|c|c|c|}
\hline Parameter & Days & Control & $\mathrm{AFB}^{1}$ & $\begin{array}{l}0.2 \% \\
\mathrm{GM}^{2}\end{array}$ & $\begin{array}{l}0.2 \% \\
\text { HSCAS }^{3}\end{array}$ & $\begin{array}{l}0.2 \% \\
\mathrm{AC}^{4}\end{array}$ \\
\hline \multirow[t]{4}{*}{$\mathrm{RBCs}, \times 10^{6} \mathrm{U} / \mathrm{l}$} & 0 & $8.26^{a}$ & $8.29^{a}$ & $8.34^{a}$ & $8.40^{a}$ & $8.25^{a}$ \\
\hline & 7 & $8.26^{\mathrm{a}}$ & $8.03^{\mathrm{a}}$ & $8.15^{a}$ & $8.33^{\mathrm{a}}$ & $8.02^{\mathrm{a}}$ \\
\hline & 14 & $8.26^{\mathrm{a}}$ & $7.01^{\circ}$ & $7.79^{b}$ & $7.25^{c}$ & $7.19^{c}$ \\
\hline & 21 & $8.26^{a}$ & $6.51^{\mathrm{cd}}$ & $7.41^{b}$ & $6.75^{c}$ & $6.43^{d}$ \\
\hline \multirow[t]{4}{*}{ WBCs, $\times 10^{3} \mathrm{U} / \mathrm{I}$} & 0 & $10.28^{a}$ & $10.33^{a}$ & $10.20^{a}$ & $10.27^{\mathrm{a}}$ & $10.21^{a}$ \\
\hline & 7 & $10.28^{a}$ & $10.09^{b}$ & $9.97^{b}$ & $10.10^{b}$ & $10.05^{b}$ \\
\hline & 14 & $10.28^{a}$ & $9.31^{b c}$ & $9.74^{b}$ & $9.43^{b c}$ & $9.12^{c}$ \\
\hline & 21 & $10.28^{a}$ & $8.55^{\mathrm{cd}}$ & $9.63^{b}$ & $8.70^{\circ}$ & $8.35^{\mathrm{d}}$ \\
\hline \multirow[t]{4}{*}{$\mathrm{HGB}, \mathrm{g} \cdot \mathrm{dl}^{-1}$} & 0 & $11.13^{a}$ & $11.08^{\mathrm{a}}$ & $11.00^{\mathrm{a}}$ & $10.98^{a}$ & $11.07^{a}$ \\
\hline & 7 & $11.13^{a}$ & $10.91^{b}$ & $10.82^{\mathrm{bc}}$ & c $10.74^{c}$ & $10.84^{b c}$ \\
\hline & 14 & $11.13^{a}$ & $10.23^{c}$ & $10.65^{b}$ & $10.19^{c}$ & $10.24^{c}$ \\
\hline & 21 & $11.13^{a}$ & $9.72^{c}$ & $10.41^{b}$ & $9.65^{c}$ & $9.62^{c}$ \\
\hline \multirow[t]{4}{*}{ HCT, \% } & 0 & $32.87^{\mathrm{a}}$ & $32.80^{a}$ & $32.67^{\mathrm{a}}$ & $32.77^{a}$ & $32.84^{a}$ \\
\hline & 7 & $32.87^{a}$ & $32.62^{\mathrm{a}}$ & $32.61^{a}$ & $32.61^{a}$ & $32.65^{a}$ \\
\hline & 14 & $32.87^{a}$ & $32.02^{c}$ & $32.57^{\mathrm{ab}}$ & b $32.19^{b c}$ & $32.05^{c}$ \\
\hline & 21 & $32.87^{\mathrm{a}}$ & $31.38^{\mathrm{cd}}$ & $32.39^{b}$ & $31.63^{c}$ & $31.11^{d}$ \\
\hline \multirow[t]{4}{*}{ MCV, fl } & 0 & $47.65^{\mathrm{a}}$ & $47.56^{\mathrm{a}}$ & $47.70^{\mathrm{a}}$ & $47.71^{a}$ & $47.68^{a}$ \\
\hline & 7 & $47.65^{a}$ & $47.56^{\mathrm{a}}$ & $47.64^{a}$ & $47.71^{\mathrm{a}}$ & $47.65^{a}$ \\
\hline & 14 & $47.65^{\mathrm{a}}$ & $47.50^{\mathrm{a}}$ & $47.58^{\mathrm{a}}$ & $47.57^{a}$ & $47.61^{\mathrm{a}}$ \\
\hline & 21 & $47.65^{a}$ & $47.47^{a}$ & $47.51^{\mathrm{a}}$ & $47.51^{a}$ & $47.61^{\mathrm{a}}$ \\
\hline \multirow[t]{4}{*}{$\mathrm{MCH}, \mathrm{pg}$} & 0 & $16.59^{a}$ & $16.53^{a}$ & $16.56^{\mathrm{a}}$ & $16.60^{a}$ & $16.51^{\mathrm{a}}$ \\
\hline & 7 & $16.59^{a}$ & $16.42^{\mathrm{a}}$ & $16.46^{a}$ & $16.42^{\mathrm{a}}$ & $16.39^{a}$ \\
\hline & 14 & $16.59^{a}$ & $15.97^{b}$ & $16.38^{a}$ & $15.94^{b}$ & $15.91^{b}$ \\
\hline & 21 & $16.59^{a}$ & $15.33^{c}$ & $16.16^{b}$ & $15.50^{\circ}$ & $15.19^{c}$ \\
\hline \multirow[t]{4}{*}{$\mathrm{MCHC}, \mathrm{g} \cdot \mathrm{dl}^{-1}$} & 0 & $35.21^{\mathrm{a}}$ & $35.27^{a}$ & $35.19^{a}$ & $35.21^{a}$ & $35.17^{a}$ \\
\hline & 7 & $35.21^{\mathrm{a}}$ & $35.07^{a}$ & $35.11^{a}$ & $35.07^{a}$ & $34.97^{\mathrm{a}}$ \\
\hline & 14 & $35.21^{\mathrm{a}}$ & $34.43^{c}$ & $34.97^{\mathrm{ab}}$ & b $34.59^{b c}$ & $34.57^{\mathrm{bc}}$ \\
\hline & 21 & $35.21^{\mathrm{a}}$ & $33.81^{\circ}$ & $34.74^{\mathrm{b}}$ & $34.03^{c}$ & $33.87^{c}$ \\
\hline
\end{tabular}

1,2,3,4 see Table 1; RBCs - red blood cells, WBCs - white blood cells, HGB - haemoglobin concentration, HCT - haematocrit levels, $\mathrm{MCV}$ - mean corpuscular volume, $\mathrm{MCH}$ - mean corpuscular haemoglobin, $\mathrm{MCHC}$ - mean corpuscular haemoglobin concentration; a,b,c,d means with different superscripts within a row differ significantly at $P<0.05$ 
change $(P>0.05)$ was observed in $\mathrm{MCV}$ due to AFB1. Our results show that among the three toxin adsorbents, supplementation of $0.2 \%$ glucomannan to the diet contaminated with AFB1 significantly reduced the adverse effect of AFB1 $(P<0.05)$ on haematology, especially on days 14 and 21 of the experiment, but could not totally overcome it. Supplementation with the two other toxin adsorbents, HSCAS and activated charcoal, at the same concentration showed a nonsignificant protective effect $(P>0.05$; Table 4$)$.

\section{Discussion}

Feed intake. The present study demonstrated decreased feed intake in response to aflatoxin B1 (AFB1) in Nili-Ravi buffaloes. Reduction of feed intake may be due to systemic stress caused by changes in the levels of tri-iodothyronine (T3) and thyroxin (T4) due to which the metabolism of the animal is disturbed (Eraslan et al., 2006). This is in accordance with the findings of Jones and Ewart (1979), who reported that an AFB1-contaminated diet $\left(0.02 \mathrm{mg} \cdot \mathrm{kg}^{-1}\right)$ caused reduced feed intake in Friesian cattle. Similarly, our results are also in line with the findings of Pasha (2008) describing a significant decrease in feed intake of Sahiwal dairy cows by feeding a $500 \mathrm{~g} \cdot \mathrm{kg}^{-1}$ AFB1-contaminated feed.

Our study also evaluated the efficacy of three different toxin binders in terms of improvement in feed intake, haematological and serum biochemistry values of experimental buffaloes. As a toxin binder that meets all of the desirable characteristics has not yet been approved by the U.S. Food and Drug Administration (FDA) for the prevention or treatment of mycotoxicoses, the evaluation of toxin binders is focused on finding one with the greatest efficacy.

Our results revealed that the negative effects of AFB1 on feed intake were mitigated by the use of glucomannan, which is in agreement with the studies of Evans and Kudupoje (2001), who reported increasing feed intake in livestock by using this binder. This could be due to the reduction of AFB1 uptake in the intestine by glucomannan, which adsorbs aflatoxin through different binding mechanisms like ionic bonds, hydrogen bonds, and different hydrophobic interactions, making aflatoxin unavailable for absorption in the intestine (Huwig et al., 2001). The increased feed intake due to glucomannan in our study is also in agreement with the findings of Wholt et al. (1991), who reported that cows given feed supplemented with yeast, which contains glucomannan in its cell wall, showed improved protein digestibility, ultimately leading to increased dry matter intake of cows.
Second in effectiveness after glucomannan was HSCAS, a silicate binder that can bind aflatoxin by chelating its $\beta$-dicarbonyl moiety with uncoordinated metal ions in the clay material. Inclusion of HSCAS at $0.5 \%$ to $2.0 \%$ of the diet has been well documented to adsorb aflatoxin and to prevent aflatoxicosis across species, including chickens, turkeys, swine, lambs, dairy cows, dairy goats and mink. Previous studies have shown that the responses to HSCAS are dose dependent. Our studies correlate with the findings of Phillips (1999), who reported that HSCAS is not a good adsorbent of mycotoxins and, therefore, is not expected to be protective against feeds containing multiple mycotoxins.

Activated carbon had the lowest efficacy in our study. This is a general adsorptive material with a large surface area. Previous studies have shown its effect at a high dose in goats (Hatch et al., 1982), other studies report variable results. Galvano et al. (1996) showed reduced aflatoxin residues in the milk of cows consuming different sources of charcoal, but responses to charcoal did not exceed those to HSCAS. This is in line with our findings. Moreover, Diaz et al. (2004) showed that low levels (45 g per cow daily) of activated carbon did not significantly reduce milk aflatoxin residues. Likewise, responses to charcoal with broilers, turkey poults, rats and mink also suggest that charcoal may not be very effective in binding aflatoxin, perhaps because of differences in physical properties.

Serum biochemistry. We found increased plasma levels of ALT, AST, ALP, total bilirubin and serum creatinine, while no change was observed in blood urea nitrogen levels of buffaloes. This is in line with the findings of Bintvihok and Kositcharoenkul (2006) showing increased levels of liver enzymes due to aflatoxin. Our findings are, however, contrary to those of Bingol et al. (2007), who studied the relation of enzymes and aflatoxin in goats and reported that there was no correlation between ALP, AST and aflatoxin concentration, instead there was a negative correlation between ALT activity and aflatoxin. Moreover, the results of our study contradict the findings of a study in Holstein cows that reported no change in ALP, ALT, or AST activity in cows fed experimentally an impure AFB1-contaminated diet at dose of $13 \mathrm{mg}$ AFB1 for 7 days (Applebaum and Marth, 1983). These conflicting results may depend upon the treatment vehicle and different species, breed and sex of experimental animals as described by Adav and Govinwar (1997).

Among the tested toxin adsorbents, glucomannan was found effective in reducing the AFB1induced increase in serum enzymes and creatinine, 
whereas the other two adsorbents (HSCAS and activated charcoal) demonstrated a lower efficacy compared with glucomannan. Similarly, an experimental study in horses showed that supplementation of a glucomannan (GM) polymer at the rate of $0.2 \%$ in feed contaminated with Fusarium mycotoxin significantly reduced the effect of this mycotoxin on serum gamma glutamyl transferase (GGT) enzyme levels (Raymond et al. 2003). Possible reasons for the difference in the efficacy of adsorbents may be due to their ability to neutralize aflatoxin at different concentrations. Phillips (1999) reported that HSCAS at a $1 \%$ inclusion level in feed diminished the adverse effects of AFB1. Activated charcoal also needs a high inclusion level for good efficacy, but at high inclusion levels essential nutrients are also adsorbed along with aflatoxin (Huwig et al., 2001).

Haematology. The present study showed that among all five groups of experimental buffaloes, the AFB1-treated group without toxin adsorbent (positive control) showed highly decreased TEC, TLC, HGB, HCT, MCH and MCHC levels compared with the group given no AFB1 (negative control). These findings are in line with other studies on haematopoiesis suppression by aflatoxin (Oguz et al., 2003). This decrease in haematological parameters may have many causes, such as a decrease in iron binding capacity (Abdel-Wahhab et al., 2002) and aflatoxin-induced haematopoietic defects in blood cells. The haematological findings of the present study are in agreement with the studies of Donmez et al. (2012), who reported decreased levels of TEC, TLC, HGB, and HCT in rams fed a $250 \mu \mathrm{g}$ AFB1contaminated diet.

Our studies also correlate with Donmez et al. (2012), who found that supplementation of glucomannan at an inclusion level of $1 \mathrm{~g}$ per day to an aflatoxin-contaminated diet significantly offset the decrease in haematological parameters, but could not bring them to normal levels.

\section{Conclusions}

Our study has demonstrated the adverse effects of alfatoxin B1 (AFB1) on feed intake, haematological and serum biochemical parameters related to liver and kidney function in Nili-Ravi buffalos. Among the tested toxin adsorbents, only $0.2 \%$ glucomannan showed good protective efficacy against AFB1, but was unable to ameliorate its effect completely, whereas hydrated sodium calcium aluminosilicates and activated charcoal showed poor efficacy in reducing AFB1-induced adverse effects on feed consumption, haematology and serum biochemistry. Further studies are needed, however, in order to analyse the effects of AFB1 and to explore the protective efficacy of toxin adsorbents in Nili-Ravi buffalo.

\section{References}

Abdel-Wahhab M.A., Nada S.A., Khalil. F.A., 2002. Physiological and toxicological responses in rats fed aflatoxin-contaminated diet with or without sorbent materials. Anim. Feed Sci. Tech. 97, 209-219

Adav S.S., Govindwar S.P., 1997. Effects of aflatoxin B1 on liver microsomal enzymes in different strains of chickens. Comp. Biochem. Physiol. Pt. C 118, 185-189

Ahmad J., 2013. Economic Survey of Pakistan, Government of Pakistan, Finance Division, Economic Adviser's Wing. Islamabad (Pakistan)

Applebaum R.S., Marth E.H., 1983. Responses of dairy cows to dietary aflatoxin: Concentration of blood serum constituents and hormones associated with liver-kidney dysfunction and maintenance of lactation. Eur. J. Appl. Microbiol. 18, 381-386

Bingol N.T., Tanritanir P., Dede S., Ceylan E., 2007. Influence of aflatoxin present in forages and concentrated feeding stuffs on milk and some serum biochemical parameters in goats. Bull. Vet. Inst. Pulawy 51, 65-69

Bintvihok A., Kositcharoenkul S., 2006. Effect of dietary calcium propionate on performance, hepatic enzyme activities and aflatoxin residues in broilers fed a diet containing low levels of aflatoxin B1. Toxicon 47, 41-46

Diaz D.E., Hagler W.M., Blackwelder Jr. J.T., Eve J.A., Hopkins B.A., Anderson K.L., Jones F.T., Whitlow L.W., 2004. Aflatoxin binders II: Reduction of aflatoxin M1 in milk by sequestering agents of cows consuming aflatoxin in feed. Mycopathologia $157,233-241$

Diaz D.E., Hagler Jr W.M., Hopkins B.A., Whitlow L.W., 2003. Aflatoxin binders I: in vitro binding assay for aflatoxin $B 1$ by several potential sequestering agents. Mycopathologia 156, 223-226

Donmez N., Donmez H.H., Keskin E., Kisadere I., 2012. Effects of Aflatoxin on Some Haematological parameters and protective effectiveness of esterified glucomannan in Merino rams. Sci. World J. 2012, doi: 10.1100/2012/342468

Donmez N., Keskin E., 2008. The effects of aflatoxin and glucomannan on some antioxidants and biochemical parameters in rabbits. Acta Vet. 58, 308-313

Eraslan G., Akdogan M., Liman B.C., Kanbur M., Delibas N., 2006. Effects of dietary aflatoxin and hydrated sodium calcium aluminosilicate on triiodothyronine, thyroxin, thyrotrophin and testosterone levels in quails. Turk. J. Vet. Anim. Sci. 30, 41-45

Evans J.W., Kudupoje M., 2001. In vitro aflatoxin binding characteristics of an esterified glucomannan product. J. Anim. Sci. 79, 330-331

Galvano F., Pietri A., Bertuzzi T., Fusconi G., Galvano M., Piva A., Piva G., 1996. Reduction of carry over of aflatoxin from cow feed to milk by addition of activated carbons. J. Food Prot. $59,551-554$

Hatch R.C., Clark J.D., Jain A.V., Weiss R., 1982. Induced acute aflatoxicosis in goats. Treatment with activated charcoal or dual combinations of oxytetracycline, stanozolol, and activated charcoal. Amer. J. Vet. Res. 43, 644-648

Huwig A., Freimund S., Kappeli O., Dutler., 2001. Mycotoxin detoxification of animal feed by different adsorbents. Toxicol. Lett. 122, 179-188 
Jones M.G., Ewart J.M., 1979. Effects on milk production associated with consumption of decorticated extracted groundnut meal contaminated with aflatoxin. Vet. Rec. 105, 492-493

Oguz H., Hadimli H.H., Kurtoglu V., Erganis O., 2003. Evaluation of humoral immunity of broilers during chronic aflatoxin (50 and $100 \mathrm{ppb}$ ) and clinoptilolite exposure. Rev. Med. Vet. 154, 483-486

Pasha T.N., 2008. Detoxification of aflatoxin by yeast sludge in the feed of dairy cattle and its impact on increased milk production. IJAVMS - Int. J. Agr. Vet. Med. Sci. 2, 18-26

Phillips T.D., 1999. Dietary clay in the chemoprevention of aflatoxin induced disease. Toxicol. Sci. 52, 118-126

Raymond S.L., Smith T.K., Swamy H.V.L.N., 2003. Effects of feeding a blend of grains naturally contaminated with Fusarium mycotoxins on feed intake, serum chemistry, and hematology of horses, and the efficacy of a polymeric glucomannan mycotoxin adsorbent. J. Anim. Sci. 81, 2123--2130
Royes J.B., Yanong R.P., 2002. Molds in fish feeds and aflatoxicosis. University of Florida, Institute of Agricultural Sciences (UF/ IFAS)

Shotwell O.L., Hesseltine C.W., Stubblefield R.D., Sorenson W.G., 1966. Production of aflatoxin on rice. Appl. Microbiol. 14, $425-428$

Sultana N., Hanif N.Q., 2009. Mycotoxin contamination in cattle feed and feed ingredients. Pakistan Vet. J. 29, 211-213

Sultana N., Rashid A., Tahira I., Khatoon S., Hanif H.U., Hanif N.Q., 2013. Distribution of various mycotoxins in compound feed, total mix ration and silage. Pakistan Vet. J. 33, 200-204

Var I., Kabak B., Erginkaya Z., 2008. Reduction in ochratoxin A levels in white wine, following treatment with activated carbon and sodium bentonite. Food Control 19, 592-598

Wholt J.E., Finkelstein A.O., Chung C.H., 1991. Yeast culture to improve intake, nutrient digestibility and performance of dairy cows in early lactation. J. Dairy Sci. 74, 1395-1400 